by Betty A. Skipp, Paul L. Brenckle, Vladimir I. Poletaev, Tamara I. Nemirovskaya, H. Richard Lane, and Walter L. Manger

\title{
The continuing international search for a Mid-Carboniferous boundary Stratotype-Donets Basin, USSR, 1988
}

In September 1988, members of the MidCarboniferous Boundary Working Group and other interested participants visited a proposed boundary stratotype section at Beshevo Reservoir in the Donets Basin of the eastern Ukraine, USSR. This trip was part of the working group's continuing effort to examine favorable stratotypes worldwide and came after excursions to the Craven Basin in the United Kingdom and to eastern Gansu Province in the People's Republic of China. The middle Carboniferous boundary at Beshevo Reservoir appears to lie within terrigenous clastic rocks between the lower and upper limestones $D_{S}^{8}$ of the Zapaltyubinsky Horizon. Work is progressing to pinpoint the stratigraphic appearance of the boundary-defining conodont Declinognathodus noduliferus and other pertinent taxa.

\section{Introduction}

The Subcommission on Carboniferous Stratigraphy (SCCS) of the International Union of Geological Sciences approved in 1983 a recommendation that a mid-Carboniferous boundary be selected at the first occurrence of the conodont Declinognathodus noduliferus in a continuously deposited sequence of rocks, a position coinciding approximately with the Eumorphoceras-Homoceras ammonoid zonal transition. This boundary would separate lower and upper subdivisions of the Carboniferous System intercontinentally (Lane and Manger, 1985a, b).

At the instigation of the SCCS, H.R. Lane organized in 1985 a working group consisting of 20 persons, representing 12 countries, to select a middle Carboniferous boundary stratotype. Since that time, the working group has examined proposed stratotypes in the United Kingdom (Craven Basin) in 1985 and in the People's Republic of China (eastern Gansu Province) in 1987 (fig. 1). In 1988, the working group visited a proposed stratotype section at Beshevo Reservoir in the Donets Basin of the eastern Ukraine, USSR (fig. 1). This report summarizes descriptions of the proposed stratotype sections in the United Kingdom and China, discusses in more detail this recent visit to the Donets Basin, and outlines future activities.

\section{Proposed stratotypes}

\section{Craven Basin, Stonehead Beck section}

The Stonehead Beck section (formerly Gill Beck) in the Craven Basin, North Yorkshire, United Kingdom (fig. 1), consists of $34 \mathrm{~m}$ (meters) of basinal Sabden Shales interbedded with minor amounts of limestone, siltstone, and sandstone. Details of the section and the sequence of its goniatites, bivalves, spores, and conodonts are published in Riley and others (1987). The section spans the Arnsbergian (Eumorphoceras 2)-Chokierian (Homoceras 1) stage boundary (fig. 2 ) and is the type locality for the goniatite (Isohomoceras subglobosum, a marker fossil for the basal Chokierian. Conodonts include Gnathodus bilineatus bollandensis and Rhachistognathus minutus in the late Arnsbergian and Declinognathodus noduliferus in the early Chokierian. A few meters of seemingly barren strata intervene between rocks that have late Arnsbergian fauna and those that have early Chokierian fauna (Lane, 1988). The section has been designated a Site of Special Interest (SSI) by the British Government to guarantee its preservation.

\section{Eastern Gansu Province, Yushuliang section}

The Yushuliang section in Jingyuan, eastern Gansu Province, People's Republic of China (fig. 1), consists of well-exposed paralic to

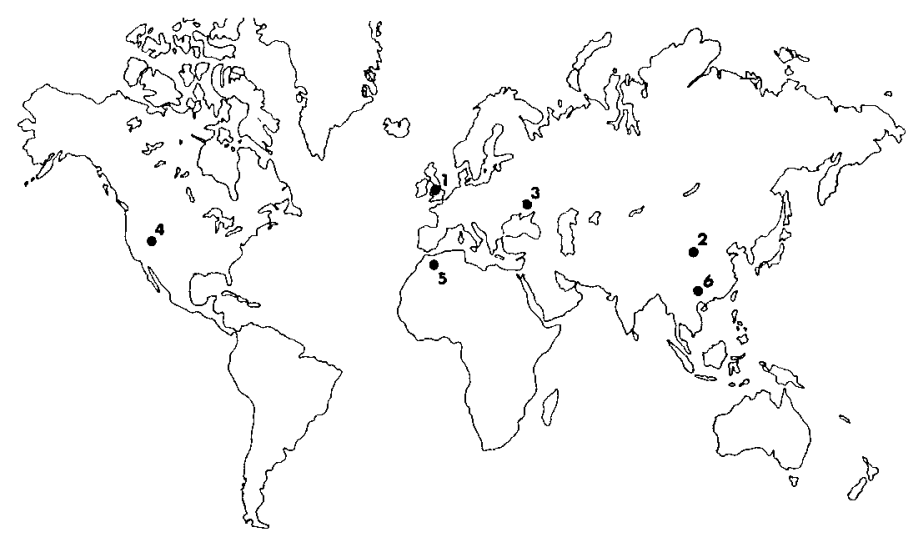

Figure 1.--Location of proposed middle Carboniferous boundary stratotypes in 1. Craven Basin (UK); 2, eastern Gansu Province (People's Republic of China); and 3, Donets Basin (USSR). Possible boundary stratotypes proposed for future examination include 4 , western Utah and southern Nevada (USA), 5, Béchar Basin (Algeria); and 6, Luosu, southern Guishou Province (People's Republic of China). 


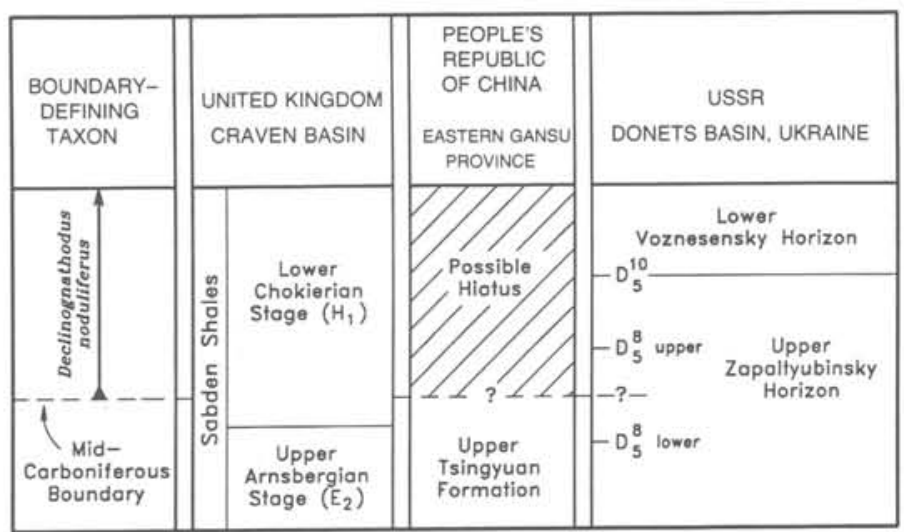

Figure 2.-Correlation chart showing middle Carboniferous boundary relationships as presently understood in the Craven Basin (from Riley and others, 1987), eastern Gansu Province (from Li and others, 1987, and Lane, 1988), and the Donets Basin (from Poletaev and others, 1988 , and this report). Abbreviations: $H_{1}$. Homoceras $I$ Zone; $E_{2}$, Eumorphoceras 2 Zone; D, limestone.

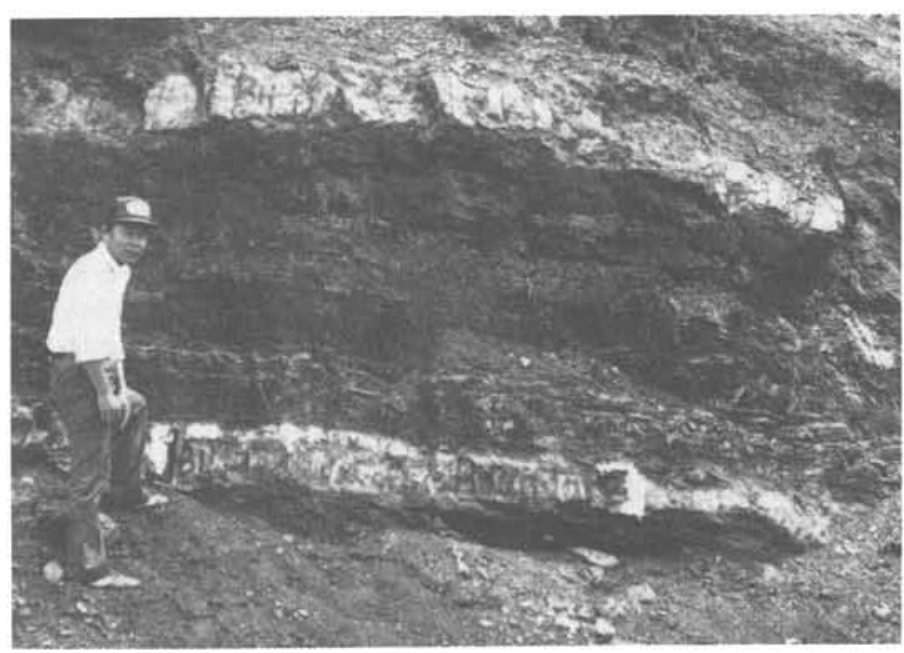

Figure 3.-Proposed middle Carboniferous boundary stratotype at Yushuliang, eastern Gansu Province, People's Republic of China. Boundary is the contact between the upper shaly mudstone of the Tsingyuan Formation and the basal limestone of the overlying Hongtuwa Formation near Wang Zhihao's left foot. Dr. Wang works for the Institute of Geology and Palaeontology, Academia Sinica, Nanjing, Jiangsu Province, People'sRepublic of China. Photo by P.L. Brenckle.

continental deposits of the Tsingyuan Formation $(50 \mathrm{~m})$ and overlying Hongtuwa Formation ( $75 \mathrm{~m})$. Lenticular limestone in the grayishblack mudstone, sandstone, and sandy conglomerate of the upper Tsingyuan Formation contain the ammonoid Eumorphoceras bisulcatum and the conodont Gnathodus bilineatus bollandensis. The conodont Declinognathodus noduliferus appears in thin limestone beds of the overlying Hongtuwa Formation (fig. 3), the base of which is the proposed middle Carboniferous boundary. Plant-bearing clastic beds separate the ammonoid- and conodont-bearing beds of the upper Tsingyuan from the basal limestone of the Hongtuwa Formation, and these clastic beds also are interbedded with the thin marine limestone beds in the basal $6 \mathrm{~m}$ of the Hongtuwa ( $\mathrm{Li}$ and others, 1987).

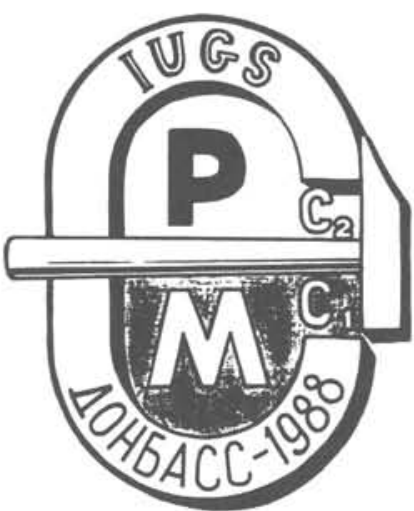

Figure 4.-Logo of the Mid-Carboniferous Boundary Working Group field excursion to the Donets Basin (Donbass), September 1988. De signed by V.I. Poletaev.

Upon cursory examination at the Yushuliang site in 1987, members of the working group and their colleagues inferred that possible gaps exist in the conodont and goniatite successions at the proposed boundary (fig. 2) and that the clastic strata between the conodont faunas in the basal Hongtuwa Formation contain some vascular land plants not found as low as the Chokierian Stage in western Europe. The Yushuliang section is being more fully studied and mapped, so that it may be better correlated. The section has good exposure, access, and a wide variety of fossils (Lane, 1988).

\section{Donets Basin, Zhelvakovaya Valley section}

In September 1988, 11 members of the Mid-Carboniferous Boundary Working Group met Soviet stratigraphers and paleontologists in Kiev, Ukraine, USSR, and were escorted to a proposed boundary stratotype section on the southwestern shore of Beshevo Reservoir in the Donets Basin southeast of the city of Donetsk (figs. 1, 4). The following voting members or their representatives participated: H.R. Lane (USA, Chairman), A C. Higgins (UK, Secretary), P.L. Brenckle (USA), O.L. Einor (USSR), E. Groessens (Belgium) representing J. Bouckaert, W.L. Manger (USA), T.I. Nemirovskaya (USSR), W.H.C. Ramsbottom (UK), Ruan Yi-ping (China), B.A. Skipp (USA), and Yang Jing-zhi (China). The American participants gratefully acknowledge travel support from the National Science Foundation (Grant EAR88-17286).

Strata in the vicinity of the Beshevo Reservoir, north of the town of Starobeshevo in the Kal'mius River valley, are beds of shallow-water limestone and terrigenous clastic rocks of both the Zapaltyubinsky Horizon (=Formation) and the overlying Voznesensky Horizon (Poletaev and others, 1988) (fig.2). The boundary between these two horizons coincides with that between the Eumorphoceras 2 and Homoceras Zones (fig. 5).

Conodont, ammonoid, and foraminiferal faunas collected from outcrops and drill holes in the Donets Basin were examined in Kiev by members of the working group and their colleagues, who determined that the middle Carboniferous boundary lies within the upper Zapaltyubinsky Horizon between limestones $\mathrm{D}_{5}^{8}$ lower and $\mathrm{D}_{5}^{8}$ upper, below limestone $\mathrm{D}_{5}^{10}$ at the base of the Voznesensky Horizon (fig. 2 ). The 5-to- $6 \mathrm{~m}$ thickness containing siltstone, sandstone, and mudstone between the lower and upper $\mathrm{D}_{5}^{8}$ limestones is present at both the Zhelvakovaya and Bezymyannaya sections on the southwestern shore of the reservoir (fig. 5, localities 1 and 2, respectively). Both collection sites were examined; the lithologies were deemed more 


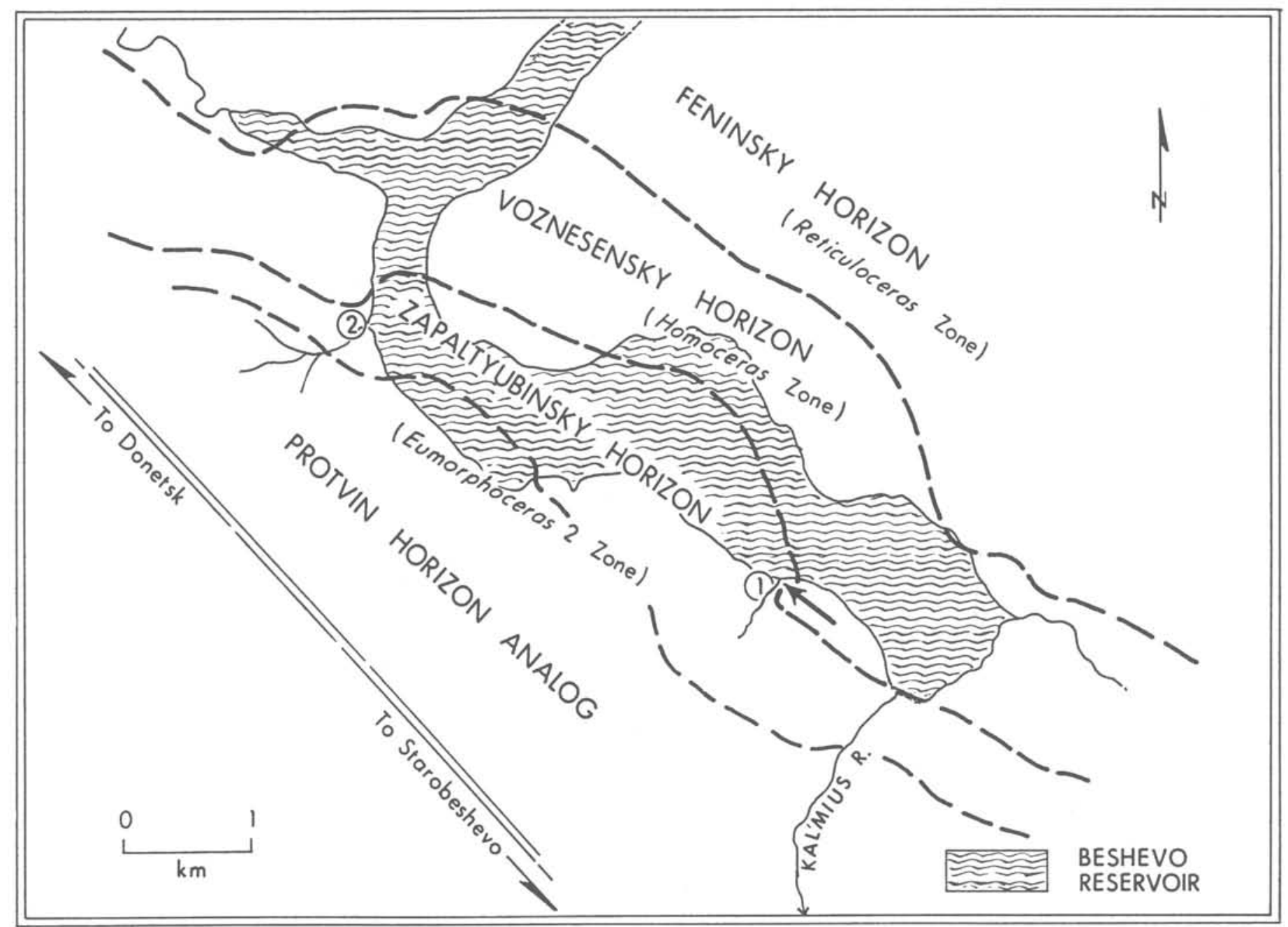

Figure 5.-Geologic map of the Beshevo Reservoir area in the Donets Basin of the Eastern Ukraine, USSR, modified from a field map used during the excursion. Locality 1, Zhelvakovaya Valley section, Locality 2, Bezymyannaya Valley section. Arrow at locality 1 points to location of trenched sections of figure 7.

favorable for fossil recoveries at Zhelvakovaya Valley, the type area for the upper part of the Zapaltyubinsky Horizon.

The lower and upper limestones $\mathrm{D}_{5}^{8}$ form ledges in several places in the Zhelvakovaya Valley. The intervening terrigenous rocks mostly are covered; therefore, trenching was necessary to expose as complete a succession as possible. Two trenches, one about $5 \mathrm{~m}$ long on the valley hillside and the other less than $2 \mathrm{~m}$ long at reservoir level, were dug with picks and shovels during an international effort that lasted $11 / 2$ days and involved at least 10 persons, including scientists from several countries and many students (fig. 6). The trenches were located approximately $100 \mathrm{~m}$ apart. Preliminary rock descriptions and thicknesses were recorded (fig. 7), and paleontologic and lithologic samples were collected. Initial examination of the trench sections did not reveal any obvious stratigraphic breaks,

Figure 6.-Five members of the Mid-Carboniferous Boundary Working Group wielding picks and shovels during trenching of the Zhelvakovana Valley hillside section ZA (fig. 7). From left to right, W.H.C. Ramsbottom and A.C. Higgins (UK), T.I. Nemirovskaya (USSR), and H.R. Lane and W.L. Manger (USA). Photo by P.L. Brenckle.

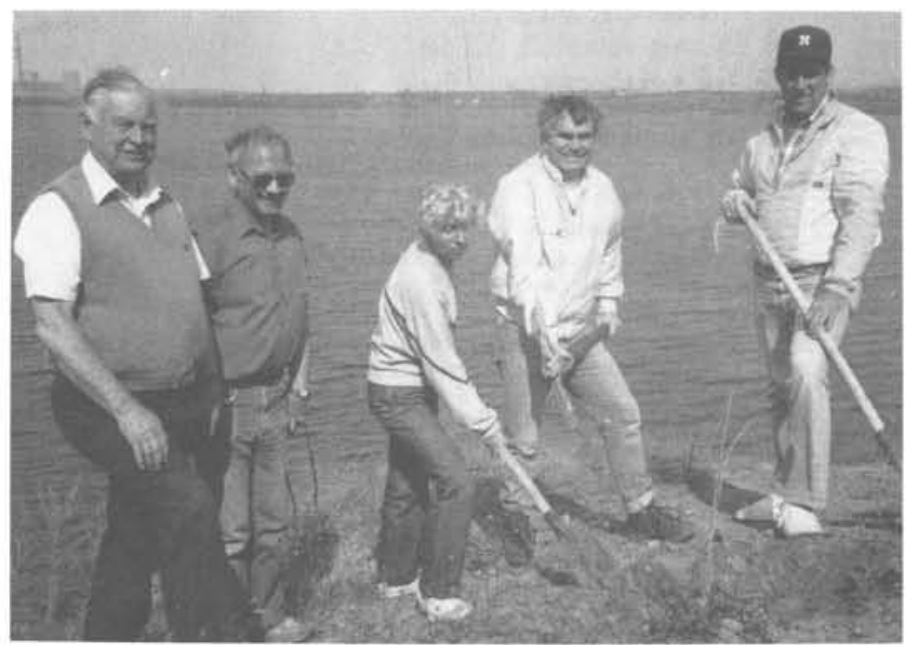


Claystone, mostly gray, some purple, yellow, and black: silty, micaceous, scattered coaly material, crudely laminated, scattered nodules, scattered plant remains; sample TS-7 from $2.5 \mathrm{ft}(0.762 \mathrm{~m})$ below top of trenched section

S-7

TS-6

Claystone, medium- to light-gray, silty, micaceous, crumbly, blocky fracture, scattered ferruginous nodules and sand stringers, not bedded; sample TS- $6,1 \mathrm{ft}$ $(0.30 \mathrm{~m})$ above sandstone

Sandstone, moderate-brown and gray, medium- to very fine grained, poorly sorted, quartzose, quartz grains rounded to angular, micaceous, ferruginous cement, upper and lower contacts sharp

Modstone, medium-gray, silty, micaceous, ferruginous S -5 stain, scattered plant remains; sample TS- 5 from basal part

Sandstone, moderate-yellowish-brown, medium- to very? fine grained, poorly sorted, quartzose, micaceous, crumbly, ferruginous cement, scattered plant debris; two beds in unit, sharp contacts

Claystone, mixed silty and nonsilty, scattered ferruginous zones, rare siderite concretions, crudely bedded. blocky fracture

Sandstone, moderate-orange-brown, medium- to finegrained, poorly sorted, quartzose, rounded to angular quartz grains, micaceous, ferruginous, contacts sharp

TS-4

Claystone, mixed silty and nonsilty, scattered ferruginous zones, rare siderite concretions, crudely bedded, low to micaceous above at $2.25 \mathrm{ft}(0.69 \mathrm{~m})$ below top: sample TS $-4,3.17 \mathrm{ft}(0.96 \mathrm{~m})$ above base; sample TS-3 from basal few inches or centimeters
Section ZB

Claystone, not exposed

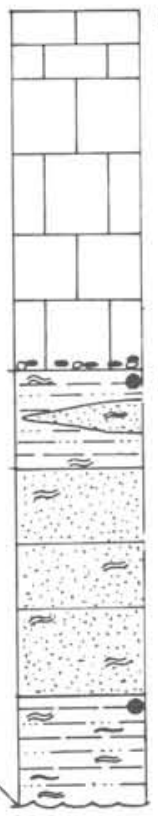

Limestone, gray, fine- to medium-grained packstone containing fossil allochems and shelly material with coated grains; abundant ferruginous material; platy weathering toward top; ferruginous gravel layer at base; lower contact sharp: $D_{5}^{8}$ upper

Claystone, medium-gray, silty, micaceous, sandstone lens, 3 in. $(7.6 \mathrm{~cm})$ to 0 thickness, present 4 in. $(10.2 \mathrm{~cm})$ above base; sandstone resembles unit below; sample from upper few inches or centimeters

Sandstone, medium-yellow-brown, very fine to mediumgrained, poorly sorted, angular to rounded grains, quartzose, micaceous, ferruginous stain, not calcareous; ferruginous and clay cement, manganese dioxide present; 3 beds of equal thickness; sharp contacts above and below

Claystone, medium-gray, silty, micaceous, crumbly, not bedded, scattered carbonaceous material; upper contact sharp; sample from upper few inches or centimeters blocky fracture: change from slightly micaceous be.

Beshevo Reservolt

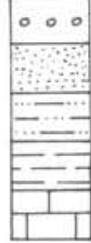

Conglomerate

Sandstone or sandy

Siltstone or silty

Mudstone or claystone

Limestone
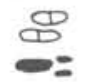

$\oplus$

$\approx$
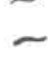

Q

- TS-1
Limestone nodules

Ironstone nodules

Siderite concretions

Micaceous

Coaly material

Sample location and number
Plant remains

TS -3

Ferruginous zone; medium- to dark-reddish-brown, silty, METER plastic mudstone containing hard ironstone nodules;

S-2 upper contact sharp and irregular; lower contact gradational

Claystone, medium- to light-gray, light-brown at top (weathered), nonsilty, unbedded, firm, not plastic, except at top; sample TS-2 from upper few inches or centimeters

Mudstone, medium-gray to reddish, plastic, not silty. contains rounded limestone nodules in lower part; limestone dark gray to moderate brown, fine-grained wackestone to packstone, ferruginous; contacts sharp but irregular

Limestone, medium-grey, coarse-grained to conglomeratic, foraminifer-algai packstone, upper contact sharp but irrugular, base not seen; sample TS-1 from upper part; $\mathrm{D}_{5}^{8}$ lower

Figure 7.-Columnar diagrams of two trenched sections be tween the $D_{5}^{8}$ lower and the $D_{5}^{8}$ upper limestones in the upper part of the Zapaltyubinsky Horizon at Zhelvakovaya Valley on the southwestern shore of Beshevo Reservoir (fig. 5, locality 1). Most of the interval is exposed in the hillside section (ZA), but the uppermost beds are found nearby in the section at reservoir level $(Z B)$. The correlation between the two sections is not exact, but local mapping suggests that they are nearly continuous or perhaps overlap. Sections described and measured by W.L. Manger and recorded by B.A. Skipp on September 22, 1988. 
but the depositional environment of the sandstone layers has yet to be determined. Detailed paleontologic and sedimentologic studies of the Zhelvakovaya Valley section are now in progress in the Soviet Union.

The working group recognizes the Zhelvakovaya Valley section as a potential boundary stratotype for the following reasons. (1) The Zapaltyubinsky Horizon contains conodont, foraminiferal, and ammonoid faunas that can be correlated worldwide. (2) Strata are relatively well exposed, are unmetamorphosed, and appear to constitute an uninterrupted succession. (3) The section contains interbedded marine faunas and terrestrial spores and megaflora. The latter groups may prove useful for determining stratigraphic continuity within the terrigenous beds across the boundary, and a detailed study of the floral distribution is critical. Beds at the top of trenched hillside section ZA (fig. 7) may be slumped, which would necessitate another excavation nearby for a section between the lower and upper limestones $D_{5}^{8}$. Access to the area by foreign scientific personnel would have to be assured if the section is to be considered a candidate for the middle Carboniferous boundary stratotype.

In September 1989, members of the Mid-Carboniferous Boundary Working Group visited proposed stratotype sections in the western United States in conjunction with the biennial meeting of the SCCS at Provo, Utah (fig. 1). Sections were examined in the Oquirrh Mountains and Confusion Range of western Utah and in Arrow Canyon in southern Nevada. The field trips were coordinated by G.D. Webster of Washington State University, Pullman, Washington.

An excursion to visit mid-Carboniferous exposures in the Béchar Basin of Algeria is planned in fall 1990, and 1992 is being considered for a visit to a proposed boundary stratotype in southern
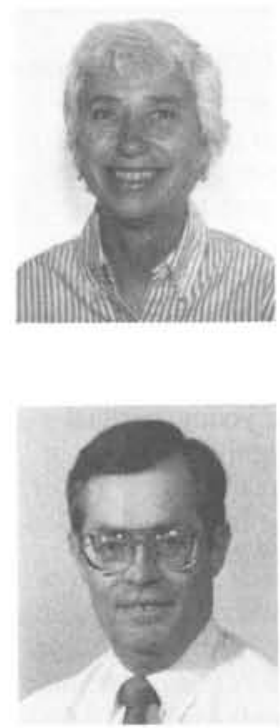

\section{B.A. Skipp is a Research Geologist} at the U.S. Geological Survey, Box 25046, M.S. 913, Denver, Colorado 80225, USA. Her research interests include structural and stratigraphic studies of Idaho and Montana and lower to middle Carboniferous calcareous foraminifers. She is a member of the Mid-Carboniferous Boundary Working Group.

P.L. Brenckle is a Research Associate at Amoco Research Center, Box 3385, Tulsa, Oklahoma 74102, USA. His work focuses on the biostratigraphy and taxonomy of lower to middle Carboniferous calcareous microfossils. He is a Titular Member of the Subcommission on Carboniferous, Chairman of the Lower Carboniferous Boundaries Working Group, and a member of the Mid-Carboniferous Boundary Working Group.

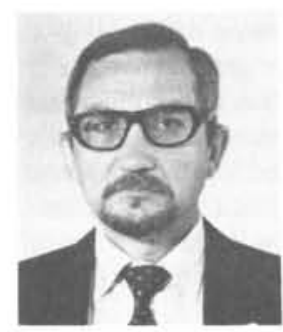

V.I. Poletaev is a Senior Scientist in the Institute of Geology, Ukrainian Academy of Sciences, ul. Chkalova $55 b, 252054 \mathrm{Kiev}$, USSR. His specialty is the study of Carboniferous brachiopods from the Donets Basin, Ukraine. He is a member of the Lower Carboniferous Boundaries Working Group.

China (fig. 1). In the intervening year, 1991, the 12th International Carboniferous-Permian Congress will convene in Argentina, where the working group will meet to discuss progress on the stratotype search.

\section{References}

Lane, H.R., 1988, Working group on the mid-Carboniferous boundary: Newsletter on Carboniferous Stratigraphy, no. 6, chapter 4.4, p. 18-19.

Lane, H.R. and Manger, W.L., 1985a, Toward a boundary in the middle of the Carboniferous (1975-1985): Ten years of progress, in: Lane, H.R., and Ziegler, W., eds., Toward a boundary in the middle of the Carboniferous: Stratigraphy and Paleontology: Courier Forschungsinstitut Senckenberg, v. 74, p. 15-34.

1985b, The basis for a mid-Carboniferous boundary: Episodes, v. 8, no. 2, p. $112-115$.

Li Xingxue, Shen Guanglong, Wu Xiuyuan, and Tong Zaishan, 1987, A proposed boundary stratotype in Jingyuan, eastern Gansu, for the Upper and Lower Carboniferous of China, in Wang Chengyuan, ed., Carboniferous boundaries in China: International Congress of Carboniferous Stratigraphy and Geology, 11th, Beijing, China, 1987, Contribution, p. 69-88.

Poletaev, V.I., Makarov, I.A., Nemirovskaya, T.I. and Maslo, A.I., compilers, 1988, The guidebook to excursion to the Lower/Middle Carboniferous boundary deposits of Donbas: Kiev, Institute of Geological Sciences, Ukrainian Academy of Sciences, $92 \mathrm{p}$.

Riley, N.J., Varker, W.J., Owens, B., Higgins, A.C., and Ramsbottom, W.H.C., 1987, Stonehead Beck, Cowling, North Yorkshire, England: A British proposal for the mid-Carboniferous boundary stratotype, in Brenckle, P.L., Lane, H.R. and Manger, W.L. eds., Selected studies in Carboniferous paleontology and biostratigraphy: Courier Forschungsinstitut Senckenberg, v. 98, p. 159-177.
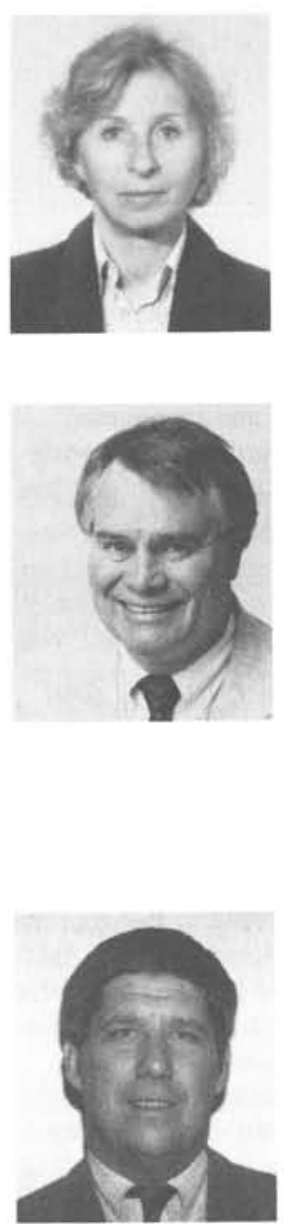

T.I. Nemirovskaya is a Senior Scientist in the Institute of Geology, Ukrainian Academy of Sciences, ul. Chkalova 55b, 252054 Kiev, USSR. She specializes in the study of Carboniferous conodonts from the Ukraine and other regions of the Soviet Union. She is a member of the Mid-Carboniferous Boundary Working Group.

H.R. Lane is a Group Supervisor in the West Texas/Eastern New Mexico Division, Amoco Production Company, Box 3092, Houston, Texas 77253, USA. His research interests include Devonian through Early Pennsylvanian conodont taxonomy, biostratigraphy, and paleozoogeography. He is a Titular Member of the Subcommission on Carboniferous Stratig. raphy and Chairman of the MidCarboniferous Boundary Working Group.

W.L. Manger is Chairman of the Geology Department at the University of Arkansas, Fayetteville, Arkansas 72701, USA. His paleontologic specialty is taxonomy and biostratigraphy of Carboniferous ammonoids. He is a member of the Mid-Carboniferous Boundary Working Group. 